\title{
Penyalutan Bakteri Asam Laktat Hasil dari Fermentasi Kulit Buah Nanas (Ananas comosus) dengan Pewarna Bunga Telang (Clitoria ternatea)
}

\section{(Encapsulation of the Lactic Acid Bacteria from Pineapple Skin (Ananas comous) Fermentation with Staining of Telang Flowers (Clitoria ternatea))}

\author{
Kyoko Itsuko Etsuko Gabriela Masengi ${ }^{1)^{*}}$, Jainer Pasca Siampa ${ }^{1)}$,Trina Ekawati Tallei ${ }^{2)}$ \\ ${ }^{1)}$ Program Studi Farmasi FMIPA UNSRAT Manado, 95115 \\ 2) Jurusan Biologi FMIPA UNSRAT Manado, 95115 \\ *etsukokyokochan@gmail.com
}

(Article History: Received 07 Juli 2020; Revised 3 Agustus 2020; Accepted 18 Agustus 2020)

\begin{abstract}
ABSTRAK
Bakteri sebagai hasil fermentasi dari kulit buah nanas (Ananas comosus) mengandung bakteri asam laktat yang dapat berperan sebagai probiotik. Agar bakteri dinyatakan sebagai probiotik bakteri harus mampu bertahan pada $\mathrm{pH}$ rendah, sehingga dilakukan penyalutan menggunakan metode ekstrusi dengan polimer alginat yang diwarnai dengan ekstrak bunga telang. Penelitian ini bertujuan untuk mengevaluasi pengaruh simulasi cairan lambung terhadap viabilitas bakteri yang disalut dengan menggunakan polimer alginat dan mengevaluasi pertumbuhan bakteri pada media De Man Rogosa and Sharpe Agar (MRSA) dan Nutrient Agar (NA). Metode penelitian terdiri dari proses fermentasi kulit buah nanas, enkapsulasi menggunakan polimer alginat dengan metode ektstrusi dan uji viabilitasnya. Hasil penelitian didapatkan bahwa terjadi pengurangan jumlah bakteri dan berat enkapsul yang disebabkan oleh $\mathrm{pH}$ rendah. Perubahan warna enkapsul terjadi setelah dipaparkan pada larutan simulan cairan lambung. Pertumbuhan bakteri pada NA lebih banyak dibandingkan dengan medium MRSA. Hal ini dikarenakan media NA merupakan media yang tidak selektif, sehingga mikroorganisme lain selain bakteri asam laktat dapat bertumbuh.

Kata Kunci: ekstrusi; enkapsulasi; fermentasi; kulit buah nanas.
\end{abstract}

\section{ABSTRACT}

Fermentation product of pineapple fruits skin (Ananas comosus) contains lactic acid bacteria $(L A B)$ which can serve as probiotics. In order to be declared as a probiotic, bacteria must be able to survive at low $\mathrm{pH}$, thus encapsulation was carried out using the extrusion method with alginate polymers dyed with telang extract. This study aims to evaluate the effect of simulated gastric fluid (GSF) on the viability of bacteria encapsulated with alginate polymers and evaluate bacterial growth on De Man Rogosa and Sharpe Agar (MRSA) and Nutrient Agar (NA). The research method consisted of the fermentation process of pineapple peel, encapsulation using the alginate polymers with the extrusion method and its viability test. The results of the study was obtained that there was a reduction in the number of bacteria and encapsule weight caused by low $\mathrm{pH}$. There were also changes in color of the microcapsules after being exposed to GSF. The bacterial growth in the NA exceeded the growth in the MRSA medium. This is due to NA is a non-selective medium, thus microorganisms besides lactic acid bacteria can grow.

Keywords: encapsulation; extrusion; fermentation; pineapple fruit skin.

\section{PENDAHULUAN}

Buah nanas merupakan salah satu buah yang tersebar di Indonesia. Salah satu bagian dari buah nanas yang jarang dimanfaatkan yaitu bagian kulit dari buah nanas. Kulit buah nanas memiliki tekstur yang tidak rata dan berduri kecil pada permukaan luarnya serta mengandung vitamin C, karotenoid dan flavonoid (Erukainure et al. 2011). Pemanfaatan kulit 
nanas pada proses fermentasi menghasilkan bakteri-bakteri asam laktat yang bermanfaat bagi kesehatan dan bersifat sebagai probiotik.

Bakteri-bakteri asam laktat hasil fermentasi kulit nanas yang bersifat probiotik dapat bermanfaat bagi kesehatan. Dalam pemanfaatannya bagi kesehatan, bakteri asam laktat akan melewati saluran pencernaan yang memiliki $\mathrm{pH}$ asam lambung yang ekstrim sehingga diperlukan metode untuk menjaga bakteri asam laktat agar tetap bertahan hidup saat melewati saluran pencernaan. Metode penyalutan (enkapsulasi) merupakan salah satu metode untuk menjaga viabilitas sel mikroba yaitu dengan melindungi sel dari faktor lingkungan luar. Penyalutan diterapkan pada bakteri seperti bakteri asam laktat (BAL) dengan tujuan untuk melindungi viabilitas bakteri sehingga tetap hidup saat dihadapi dengan kondisi ekstrim akibat pengeringan, penyimpanan, maupun cairan saluran pencernaan (Kailasapathy 2002).

Bunga telang merupakan jenis bunga lokal yang menghasilkan pigmen yang sebagian besar merupakan antosianin yang dapat digunakan sebagai pewarna alami. Secara tradisional bunga telang digunakan sebagai pengobatan anti tumor, anti asma dan dapat menurunkan tekanan darah (Jin et al. 2003). Penelitian ini bertujuan untuk mengevaluasi pengaruh simulasi cairan lambung terhadap viabilitas bakteri yang disalut dengan menggunakan polimer alginat dan mengevaluasi pertumbuhan bakteri pada media De Man Rogosa and Sharpe Agar (MRSA) dan Nutrient Agar (NA).

\section{METODOLOGI PENELITIAN}

Penelitian ini terdiri atas proses fermentasi kulit buah nanas yang setelah itu diukur kadar asam, kadar alkohol, perubahan $\mathrm{pH}$, kemudian bakteri hasil fermentasi kulit buah nanas dienkapsulasi menggunakan polimer alginat dengan metode ektstrusi dan menggunakan pewarna bunga telang dan diuji viabilitasnya pada larutan simulasi lambung $\mathrm{pH}$ 1,5.

\section{Prosedur Penelitian \\ Persiapan Sampel}

Buah nanas dicuci hingga bersih dan dipisahkan bagian daging dan kulitnya. Kulit buah nanas dipotong kecil-kecil untuk mempermudah proses fermentasi.

\section{Fermentasi Kulit Buah Nanas}

Fermentasi kulit buah nanas menggunakan metode modifikasi yang mengacu pada (Raji et al. 2012). Fermentasi dilakukan selama tujuh hari dengan merendam $300 \mathrm{~g}$ kulit buah nanas ke dalam wadah fermentasi yang berisih 350 $\mathrm{ml}$ air dan $80 \mathrm{~g}$ gula kemudian diaduk hingga homogen. Selama fermentasi, dilakukan pengukuran kadar alkohol, kadar asam dan nilai $\mathrm{pH}$.

\section{Pengukuran Kadar Asam dan Alkohol}

Kadar asam dan alkohol diukur menggunakan titrasi asam basa secara alkalimetri. Sebanyak $10 \mathrm{ml}$ larutan sampel dimasukkan ke dalam Erlemeyer dan ditambahkan 3 tetes indikator PP kemudian dititrasi dengan $\mathrm{NaOH} 0,1 \mathrm{~N}$ hingga larutan berwarna merah muda stabil. Volume dari hasil titrasi $\mathrm{NaOH}$ dimasukkan ke rumus perhitungan kadar asam dan kadar alkohol.

Rumus perhitungan kadar asam menurut Jannah et al. (2014):

$$
\text { Total Asam } \%=\frac{V_{1} \times N \times B}{V_{2} \times 1000}
$$

Keterangan:

$\mathrm{V}_{1}$ : Volume $\mathrm{NaOH}(\mathrm{ml})$

$\mathrm{V}_{2}$ : Volume Sampel (ml)

$\mathrm{N}$ : Normalitas $\mathrm{NaOH}(0,1 \mathrm{~N})$

B: Berat Molekul Asam. Laktat (90)

Hasil rata-rata dari titrasi yang diperoleh dimasukkan ke dalam perhitungan kadar alkohol menggunakan rumus yang mengacu kepada Yulianti (2014) :

\footnotetext{
Kadar alkohol (\%): $\frac{a \times M \times B E \times \text { pengenceran }}{\text { volume sampel } \times 100} \times 100 \%$

Keterangan:

a: rata-rata $\mathrm{NaOH} 0,1 \mathrm{~N}$

BE: Berat Ekivalen (46)

M: Molaritas $\mathrm{NaOH}(0,1 \mathrm{~N})$
} 


\section{Pengukuran pH}

Nilai $\mathrm{pH}$ larutan diukur menggunakan $\mathrm{pH}$ Universal. Kertas $\mathrm{pH}$ dimasukkan ke dalam $10 \mathrm{ml}$ larutan kurang lebih $2 \mathrm{~cm}$. Perubahan warna kertas $\mathrm{pH}$ Universal setelah 30 detik dicocokkan dengan warna standar pH Universal.

\section{Perhitungan Populasi Bakteri}

Pertumbuhan bakteri pada penelitian ini menggunakan metode pour plate dan perhitungan bakteri menggunakan metode total plate count. Sebanyak $1 \mathrm{ml}$ cairan fermentasi ditambahkan ke dalam $9 \mathrm{ml} \mathrm{NaCl} \quad 0,9 \%$ sehingga diperoleh pengenceran $10^{-1}$. Pengenceran dilakukan hingga mendapatkan pengenceran $10^{-5}$. Selanjutnya, untuk setiap pengenceran sebanyak $50 \mu$ l larutan diambil menggunakan mikropipet dan dimasukkan ke dalam cawan petri. Kemudian sebanyak $15 \mathrm{ml}$ medium dimasukan ke dalam cawan petri lalu diratakan dengan memutar cawan petri. Selanjutnya, cawan petri dibungkus dengan plastic wrap dan aluminium foil. Masingmasing cawan petri dimasukkan ke dalam inkubator untuk diinkubasi selama 48 jam pada suhu $37^{\circ} \mathrm{C}$. Koloni yang tumbuh dihitung menggunakan colony counter. Perhitungan jumlah sel yang membentuk koloni (colony forming unit atau CFU) dilakukan dengan menggunakan rumus Pradikaningrum (2015).

$$
C f u / m l=\frac{\text { Jumlah Koloni }}{\text { Volume yang disebar dicawan petri } \mathrm{x}}
$$

\section{Pembuatan Larutan $\mathrm{CaCl}_{2} \mathbf{0 , 1 M}$}

Larutan pengeras $\mathrm{CaCl}_{2}$ dibuat dengan melarutkan sebanyak 7,35 g CaCl 2 dalam 500 $\mathrm{ml}$ akuades kemudian diaduk hingga homogen. Larutan disterilkan menggunakan autoklaf pada suhu $121^{\circ} \mathrm{C}$ selama 15 menit dengan tekanan 1 atm.

\section{Ekstraksi Bunga Telang}

Ekstraksi dilakukan menggunakan metode ekstraksi digesti yang bertujuan untuk menarik senyawa antosianin yang terkandung dalam bunga telang menggunakan air destilasi. Ekstraksi dilakukan dengan merebus $100 \mathrm{~g}$ bunga telang dalam $500 \mathrm{ml}$ air destilasi pada suhu $50^{\circ} \mathrm{C}$ dan dilakukan pengadukan kontinu.

\section{Pembuatan Larutan Alginat}

Pembuatan larutan dilakukan dengan konsentrasi 2\%. Sebanyak $1 \mathrm{~g}$ bubuk natrium alginat dilarutkan dalam $50 \mathrm{ml}$ ekstrak bunga telang lalu disterilkan menggunakan autoklaf pada suhu $121^{\circ} \mathrm{C}$ selama 15 menit dengan tekanan $1 \mathrm{~atm}$.

\section{Penyalutan Bakteri Hasil Fermentasi}

Penyalutan dilakukan pada hari ke empat dengan menggunakan metode ekstrusi. Sebanyak $50 \mathrm{ml}$ suspensi bakteri ditambahkan ke dalam $50 \mathrm{ml}$ larutan hidrokoloid natrium alginat. Larutan alginat yang mengandung suspensi bakteri kemudian diteteskan ke dalam larutan pengeras $\left(\mathrm{CaCl}_{2}\right)$ menggunakan syringe sehingga terbentuk beads (Krasaekoopt et al. 2003).

\section{Pengujian Viabilitas Enkapsulasi pada Simulan Cairan Lambung}

Sebanyak $1 \mathrm{~g}$ bakteri terenkapsulasi dipaparkan di dalam $10 \mathrm{ml}$ larutan simulasi cairan lambung steril $\mathrm{pH} 1,5(0,9 \% \mathrm{NaCl}$, $\mathrm{HCl}$ pekat 12 tetes) kemudian diinkubasi pada suhu $37^{\circ} \mathrm{C}$ selama 120 menit. Setelah diinkubasi, bakteri terenkapsulasi dicuci dengan larutan $\mathrm{NaCl} \quad 0,9 \%$ steril dan ditimbang beratnya. Kemudian bakteri terenkapsulasi dilarutkan dengan $\mathrm{NaCl}$ 0,9\% dan bakteri yang larut ditanam dalam media NA dan media MRSA untuk melihat banyaknya bakteri yang bertahan.

\section{HASIL DAN PEMBAHASAN \\ Fermentasi}

Pengukuran dilakukan untuk melihat perubahan-perubahan yang terjadi selama 7 hari fermentasi, baik perubahan kadar asam dan kadar alkohol, maupun pertumbuhan bakteri dan perubahan $\mathrm{pH}$. Dilihat dari hasil yang diperoleh bahwa semakin lama dilakukan fermentasi terhadap kulit buah 
nanas maka $\mathrm{pH}$ larutan fermentasi akan semakin menurun (Tabel 1, Tabel 2 dan Gambar 1). Hal ini terjadi karena adanya akumulasi produk yang dihasilkan oleh asam-asam organik dari Bakteri Asam Laktat (BAL) seperti asam laktat, asam asetat ataupun asam piruvat yang menyebabkan larutan fermentasi menjadi asam dan pHnya menurun (Lin et al. 2012).

Tabel 1. Hasil pengukuran $\mathrm{pH}$ dari fermentasi kulit buah nanas

\begin{tabular}{ccc}
\hline Hari ke- & Nanas & Blanko \\
\hline 1 & 5 & 7 \\
2 & 4 & 5 \\
3 & 4 & 5 \\
4 & 4 & 5 \\
5 & 4 & 4 \\
6 & 4 & 4 \\
7 & 3 & 4 \\
\hline
\end{tabular}

Tabel 2. Perhitungan kadar alkohol

\begin{tabular}{cc}
\hline Hari ke- & Kadar Alkohol (\%) \\
\hline 1 & 0,01725 \\
2 & 0,046 \\
3 & 0,14777 \\
4 & 0,30705 \\
5 & 0,43872 \\
6 & 0,61525 \\
7 & 0,71012 \\
\hline
\end{tabular}

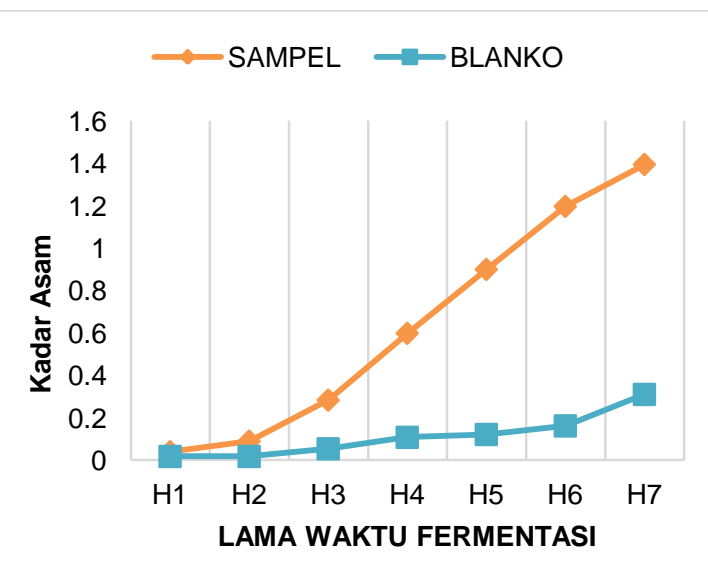

Gambar 1. Kadar asam total (Ket: H1 hari pertama, $\mathrm{H} 2$ hari kedua, $\mathrm{H} 3$ hari ke 3, $\mathrm{H} 4$ hari ke 4, H5 hari ke 5, H6 hari ke 6 dan $\mathrm{H} 7$ hari ke 7 Fermentasi
Peningkatan asam dan alkohol yang semakin tinggi menurut Ayu et al. (2012) terjadi karena adanya pengaruh dari mikroorganisme. Ketika fermentasi terjadi, mikroba secara anaerob akan menggunakan glukosa sebagai energi untuk memproduksi alkohol yang menyebabkan kenaikan kadar alkohol, dan bakteri yang mensintesis alkohol menjadi fraksi lain diantaranya menjadi asam sehingga total asam yang dihasilkan juga semakin tinggi.

\section{Penanaman Bakteri Tanpa Penyalutan}

Pertumbuhan bakteri pada media NA dan media MRSA menunjukkan adanya perbedaan jumlah bakteri yang tumbuh. Bakteri yang bertumbuh pada media NA lebih banyak dibandingkan dengan pertumbuhan bakteri pada MRSA. Hal ini dikarenakan media MRSA yang ditambah dengan $\mathrm{CaCO}_{3}$ merupakan media selektif untuk pertumbuhan bakteri asam laktat, sedangkan media NA merupakan media yang tidak selektif sehingga semua bakteri dapat tumbuh pada media.

Pertumbuhan bakteri mulai meningkat pada hari ke-3 dan terjadi penurunan pertumbuhan pada hari ke-7. Peningkatan pertumbuhan bakteri terjadi karena bakteri telah memasuki fase logaritmik, dimana bakteri telah beradaptasi dan mampu memanfaatkan nutrisi yang ada di sekitarnya sehingga pertumbuhan menjadi sangat cepat dan menyebabkan terjadinya peningkatan total bakteri. Penurunan pertumbuhan bakteri dapat disebabkan oleh habisnya nutrisi yang ada dalam media dan habisnya energi cadangan dari dalam sel sehingga terjadi kematian bakteri dan penurunan pertumbuhan bakteri

Pertumbuhan bakteri dapat dilihat pada Gambar 2. Terlihat adanya penurunan pertumbuhan bakteri di NA pada hari ke-5 dan kembali naik pada hari ke-6. Hal ini disebabkan karena media NA merupakan media non selektif sehingga semua jenis mikroba dapat tumbuh pada media ini. Semua mikroba yang tumbuh memiliki 
siklus hidup yang berbeda dan membutuhkan nutrisi yang berbeda. Penurunan dan peningkatan yang pesat terjadi karena adanya interaksi bakteri satu dengan bakteri yang lain (Agung 2011). Arfiani (2010) juga mengatakan bahwa setiap jenis spesies bakteri dalam pertumbuhannya mempunyai rentang waktu tertentu, sehingga pada saat pertumbuhan bakteri menurun ada salah satu atau lebih bakteri yang pertumbuhannya meningkat.

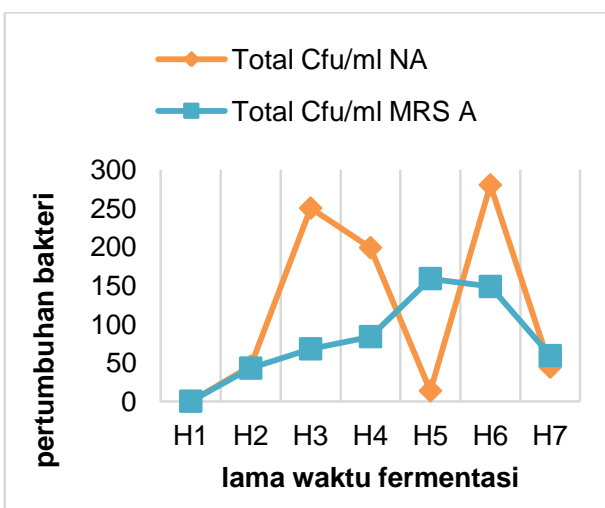

Gambar 2. Total pertumbuhan bakteri selama 7 hari (Ket: $\mathrm{H} 1$ hari pertama, $\mathrm{H} 2$ hari kedua, $\mathrm{H} 3$ hari ke 3, $\mathrm{H} 4$ hari ke 4, H5 hari ke 5, H6 hari ke 6 dan H7 hari ke 7 Fermentasi)

\section{Enkapsulasi dan Uji Viabilitas}

Enkapsulasi yang terbentuk dari reaksi ikatan silang antara alginat dan $\mathrm{CaCl}_{2}$ dalam penelitian ini menggunakan dua ukuran syringe untuk membentuk beads yaitu syringe dengan ukuran $3 \mathrm{ml}$ dan $5 \mathrm{ml}$. Beads yang terbentuk dari hasil penyalutan diuji viabilitasnya dalam larutan simulan lambung pH 1,5 (Gambar 3)

Hasil penyalutan terlihat bahwa penyalutan yang menggunakan syringe yang lebih kecil $(3 \mathrm{ml})$ membentuk beads yang sempurna dan memiliki ukuran yang sama antara satu dan lainnya. Sedangkan bakteri yang disalut menggunakan syringe yang berukuran lebih besar $(5 \mathrm{ml})$ memiliki berbagai macam bentuk yang tidak beraturan.

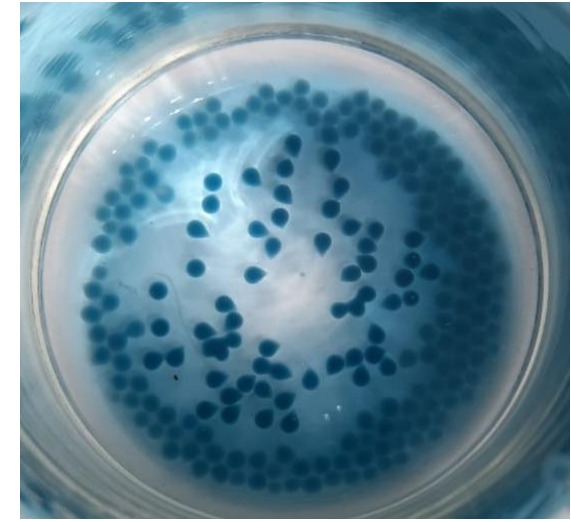

Gambar 3. Enkapsulasi dengan pewarna bungan telang menggunakan syringe $3 \mathrm{ml}$

Pengujian bakteri terenkapsulasi yang dipaparkan dalam larutan simulant asam lambung dan diinkubasi selama 48 jam menunjukkan bahwa terjadi perubahan warna yang disebabkan oleh $\mathrm{pH}$ rendah. Pemaparan pada $\mathrm{pH}$ rendah juga mempengaruhi kelarutan dari bahan enkapsul yang menyebabkan berkurangnya berat dari enkapsulasi dari $1 \mathrm{~g}$ menjadi $0,3796 \mathrm{~g}$ untuk syringe dengan volume $3 \mathrm{ml}$ dan $0,4667 \mathrm{~g}$ untuk syringe dengan volume $5 \mathrm{ml}$.

\section{Penanaman Bakteri Terenkapsulasi yang dipaparkan pada Larutan Simulan Cairan Lambung}

Penanaman bakteri dilakukan kembali untuk melihat banyaknya bakteri yang bertahan selama pemaparan dan dihitung menggunakan Colony Counter dan total koloni yang dihitung mengikuti standar perhitungan analisis Total Plate Count yaitu batas minimum $30 \mathrm{Cfu} / \mathrm{ml}$ dan batas maksimumnya $300 \mathrm{Cfu} / \mathrm{ml}$.

Hasil perhitungan bakteri yang disalut menggunakan syringe volume $3 \mathrm{ml}$ lebih banyak tersisa dibandingkan dengan bakteri yang disalut menggunakan syringe volume 5 $\mathrm{ml}$. Hal ini dikarenakan enkapsulasi dengan ukuran yang lebih kecil memiliki kapasitas retensi yang lebih tinggi dalam merangkap atau menjerap BAL (Tabel 3 dan Tabel 4). 
Tabel 3. Perhitungan bakteri terenkapsulasi yang dipaparkan pada larutan simulan

$\frac{\text { MRSA }}{3 \mathrm{ml}} 5 \mathrm{ml}$

Ukuran

Pengenceran

\begin{tabular}{lll}
\hline $10^{-1}$ & 225 & 148 \\
$10^{-2}$ & 112 & 40 \\
$10^{-3}$ & 231 & 7 \\
$10^{-4}$ & 137 & 4 \\
$10^{-5}$ & 23 & 2 \\
\hline $\mathrm{Cfu} / \mathrm{ml}$ & $7,57375 \times 10^{6}$ & $0,0548 \times 10^{6}$ \\
\hline Ket: $10^{-1}$ pengenceran ke $1,10^{-2}$ pengenceran ke $2,10^{-}$ \\
32 Pengenceran ke 3, $10^{-4}$ pengenceran ke 4 dan $10^{-5}$ \\
pengenceran ke 5.
\end{tabular}

Tabel 4. Perhitungan bakteri terenkapsulasi yang dipaparkan ada larutan simulan

\begin{tabular}{c} 
MRSA \\
\hline $3 \mathrm{ml}$
\end{tabular}

Ukuran

Pengenceran

\begin{tabular}{lll}
\hline $10^{-1}$ & 39 & 17 \\
$10^{-2}$ & 36 & 13 \\
$10^{-3}$ & 33 & 12 \\
$10^{-4}$ & 18 & 10 \\
$10^{-5}$ & 5 & 9 \\
\hline $\mathrm{Cfu} / \mathrm{ml}$ & $0,2466 \times 10^{6}$ & (tidak bisa \\
& & dihitung) \\
\hline
\end{tabular}

Ket: $10^{-1}$ pengenceran ke $1,10^{-2}$ pengenceran ke $2,10^{-}$

${ }^{3}$ Pengenceran ke $3,10^{-4}$ pengenceran ke 4 dan $10^{-5}$ pengenceran ke 5 .

Bakteri terenkapsulasi menggunakan syringe $5 \mathrm{ml}$ tidak dapat dihitung karena tidak memenuhi batas minimum dari standar perhitungan analisis Total Plate Count yaitu $30 \mathrm{Cfu} / \mathrm{ml}$.

\section{KESIMPULAN}

Bakteri hasil dari fermentasi kulit buah nanas dapat dienkapsulasi menggunakan polimer alginat dengan metode ekstrusi. Pemaparan larutan simulan lambung terhadap bakteri terenkapsulasi menyebabkan terjadinya perubahan warna dari biru menjadi merah muda, pengurangan jumlah bakteri dan berat enkapsul yang disebabkan oleh $\mathrm{pH}$. Pertumbuhan bakteri pada media NA dan MRSA, menunjukkan terjadinya perbedaan.

\section{DAFTAR PUSTAKA}

Agung FE (2011) Uji Viabilitas Konsorsium Bakteri Biodekomposer Selama Dua Bulan Duna Menentukan Waktu Inokulum Yang Optimal [skripsi]. Universitas Islam Negeri Maulana Malik Ibrahim, Malang.

Afriani (2010) Pengaruh Penggunaan Starter Bakteri Asam Laktat Lactobacillus plantarum dan Lactobacillus fermentum Terhadap Total Bakteri Asam Laktat, Kadar Asam dan Nilai pH Dadih Susu Sapi. Jurnal Ilmiah Ilmu-Ilmu Peternakan. 8(6).

Ayu P, Elfita, Aryawati R (2012) Pengaruh Waktu Fermentasi Terhadap Sifat Fisik dan Kimia pada Pembuatan Minuman Kombucha dari Rumput Laut sargassum sp. Jurnal Maspari. 2012. 4(1): 131136.

Buckle KA (1987) Ilmu Pangan. UI Press, Jakarta.

Erukainure OL, Oke OV, Ajiboye AJ, Okafor OY (2011) Nutritional qualities and phytochemical constituents of Clerodendrum volubile, a tropical nonconventional vegetable. International Food Research Journal 18(4):1393-1399.

Haryo BRS, Dewantari HK, Sri BJL, Khusniati T (2018) Pengembangan Teknologi Mikroenkapsulasi Bakteri Probiotik dan Manfaatnya untuk Kesehatan. Jurnal Veteriner. 4(19):1-17. Jannah AM, Legowo, Pramono YB, AlBaarri AN, Abduh SBM (2014) Total Bakteri Asam Laktat, pH, Keasaman, Citarasa dan Kesukaan Yogurt Drink dengan Penambahan Ekstrak Buah Belimbing. Jurnal Aaplikasi Teknologi Pangan. 3(2).

Jin JM, CR Yang (2003) Two new spirostanol sapogenins from fermented 
leaves of Agave americana. Chin. Chem. Lett. 14:491-494

Kailasapaty, Kaila

Microencapsulation of Probiotic Bacteria: Technology and Potential Applications. Curr. Issues Intest. Microbiol. 3:39-40.

Krasaekoopt WB, Bhandari, H Deeth (2003) Evaluation of Encapsulation Techniques of Probiotics for Yoghurt. Int Dairy J. 13: 3-13

Mokkaram RR (2009) The influence of multi stage alginat coating on survivability of potential probiotic bacteria in simulated gastric and intestinal juice. Food Research International. 1040-1045.

Raji YO, Jibril M, Misau IM, Danjuma BY (2012) Production of vinegar from pineapple peel. Int. J. Adv. Sci. Res. Technol. 3: 656-666

Yulianti CH (2014) Uji Beda Kadar pada Tape Beras, Ketan Hitam dan Singkong. Jurnal Teknika. 1(6). 